DUNAMIS (Jurnal Teologi dan Pendidikan Kristiani)

Volume 1, Nomor 2 (April 2017)

ISSN 2541-3937 (print), 2541-3945 (online)

http://www.sttintheos.ac.id/e-journal/index.php/dunamis

Submitted: 22 April 2017

Accepted: 29 April 2017

Published: 30 April 2017

\title{
Menstimulasi Kualitas Kehidupan Rohani dalam Meningkatkan Kemandirian Belajar Mahasiswa: Studi Refleksi Daniel 6:1-4
}

\author{
Agustin Soewitomo Putri \\ Prodi Teologi Sekolah Tinggi Teologi Torsina Surakarta \\ agustin_suwitomoputri@yahoo.com
}

\begin{abstract}
This article has purpose to show the importance of giving stimulation from the lecturer of STT Torsina to enhance the quality of student's living, either in intelectual, social and spiritual aspect. This research uses qualitative approach with exposition of text Daniel 1-6. Ini this biblical narrative Daniel gained the highest position after the king in Babylon kingdom. Daniel chosen was based on his self quality over anyone became candidates. The exposition of Daniel 6:1-4 giving some references made him been qualified, that is Daniel's spiritual life quality. By this research finding giving a recommendation of stimulate spiritual living for enhance STT Torsina students' academic quality according to Daniel.
\end{abstract}

Keyword: Daniel, self learning, spiritual quality, spiritual life's stimulating

\begin{abstract}
Abstrak
Artikel ini bertujuan untuk menunjukkan pentingnya stimulasi yang diberikan oleh para tenaga pengajar (dosen) di STT Torsina untuk meningkatkan kualitas hidup mahasiswa, baik dalam aspek intelektual, sosial dan kerohanian. Penelitian ini menggunakan pendekatan kualitatif dengan menerapkan studi eksposisi kitab Daniel 1-6. Dalam narasi biblikal ini Daniel memperoleh posisi tertinggi setelah raja di negeri Babel. Pemilihan Daniel dilandaskan pada kualitas Daniel yang mengungguli siapa pun yang menjadi calon pemimpin saat itu. Kajian eksposisi Daniel 6:1-4 mereferensikan apa yang membuat Daniel berkualitas, yaitu: kualitas kehidupan rohani Daniel. Dengan temuan ini, maka penelitian recomendation sebuah stimulasi kehidupan rohani demi meningkatkan kualitas akademis mahasiswa STT Torsina sesuai dengan tokoh Daniel.
\end{abstract}

Kata kunci: Daniel, kemandirian belajar, kualitas rohani, stimulasi kehidupan rohani 


\section{PENDAHULUAN}

Kegiatan atau proses belajar belajar di kelas dalam konteks pendidikan tinggi teologi merupakan suatu hal yang penting diperhatikan. Jangan muncul anggapan seolah sekolah teologi tidak membutuhkan pola pembelajaran yang serius hingga ke level yang tinggi, karena ilmunya hanya digunakan dalam konteks pelayanan gerejawi. Proses belajar di kelas akan berdampak pada hasil atau prestasi belajar peserta didik, dalam hal ini mahasiswa. Dan, akan seperti pelayanan yang dilakukan oleh mereka, atau transfer pengetahuan yang diberikan kepada jemaat gereja ditentukan seberapa serius mahasiswa teologi melakoni proses belajar di sekolah tinggi teologi. Sehingga penting mengupayakan interaksi belajar yang berkualitas, yang pada akhirnya akan menghasilkan mahasiswa yang berkualitas. Kehadiran dosen juga menjadi pengaruh yang penting, karena idealnya apa yang didapatkan mahasiswa tentu berasal dari kemampuan dosen yang mengajar.

Pergumulan tentang proses belajar yang berkualitas bukan hanya menjadi impian sekolah tinggi di mana kami melayani, semua sekolah menginginkan pencapaian itu. Banyak cara yang dilakukan dengan menerapkan berbagai program dan strategi demi terciptanya sebuah situasi belajar yang berkualitas. Insitutsi pun mencoba melengkapi fasilitas penunjuang demi terjadinya proses belajar yang menyenangkan. Proses belajar tidak hanya berfokus pada apa yang dilakukan di kelas, melainkan juga proses belajar yang diusahakan oleh mahasiswa secara mandiri.

Persoalan minat dan motivasi dalam belajar sepertinya menjadi persoalan dari masa ke masa, termasuk dalam lingkup perkuliahan di institusi teologi. Minat belajar berpotensi memengaruhi prestasi belajar para peserta didik, demikian juga motivasi. Menurut J.T. Lochmono Lobby, "Minat adalah kecenderungan untuk merasa tertarik atau terdorong untuk memperhatikan seseorang, sesuatu barang atau kegiatan dalam bidang- bidang tertentu." ${ }^{1}$ Jika dikaitkan dengan belajar maka itu berarti kecenderungan mahasiwa untuk tertarik atau menyukai dan memperhatikan proses belajar atau materi pelajaran yang disampaikan. Sedangkan Menurut Sadirman, "Motivasi adalah proses yang memberi semangat, arah dan kegigihan perilaku." ${ }^{, 2}$ Dalam hal ini berarti

\footnotetext{
${ }^{1}$ J.T. Lochmono Lobby, Belajar Bagaimana Belajar (Jakarta: BPK Gunung Mulia, 1994), 26

${ }^{2}$ Sadirman, Media Pembelajaran (Jakarta: Raja Grafindo, 2006), 186.
} 
bagaimana mahasiswa memiliki semangat dan kegigihan dalam belajar.

Kedua hal klasik ini akan terus ada dan memberikan pengaruh terhadap kegiatan belajar hingga kapan pun, karena persoalan minat dan motivasi lebih banyak muncul dari dalam diri mahasiswa. Harus ada sesuatu yang memunculkan itu atau meningkatkannya menjadi tinggi. Ketika minat atau motivasi belajar mahasiswa tinggi, maka akan muncul kemandirian belajar. Jika ini sudah ada, maka niscaya persoalan-persoalan lain dalam belajar akan lebih mudah diselesaikan, karena mahasiswa secara prinsip telah menemukan kemandiriannya dalam belajar.

Kemandirian belajar bukan sekadar proses belajar sendiri, tanpa dibimbing atau dipandu dosen. Kemandirian belajar merupakan kualitas belajar mahasiswa yang secara tidak langsung menunjukkan ketidakbergantungan terhadap orang lain, memiliki kepercayaan diri, inisiatif, tanggung jawab, disiplin dan kontrol diri. ${ }^{3}$ Paradigma belajar mahasiswa harus lebih berkembang dari pola berpikir dan belajar pendidikan menengah, seperti SMA atau SMK. Namun tidak sedikit mahasiswa sulit

\footnotetext{
${ }^{3}$ Kana Hidayati dan Endang Listiyani, "Pengembangan Instrumen Kemandirian Belajar Mahasiswa", Jurnal Penelitian dan Evaluasi Pendidikan, Tahun 14, No. 1, 2010: 98
}

mengalami masa transisi pendidikan menengah ke pola belajar pendidikan tinggi. Mereka masih terpola dengan paradigma pendidikan yang sebelumnya. Dan ketika masuk dalam pola-pola belajar yang menuntut kemandirian, beberapa mahasiswa agak kewalahan.

Situasi itu tidak berdiri sendiri seperti demikian, karena selain faktor mahasiswa faktor dosen pun memberikan pengaruh yang besar dalam proses belajar. Kemampuan seorang dosen juga berpengaruh dalam kelangsungan proses belajar di kelas, sehingga dosen dituntut untuk mengembangkan pola mengajarnya, baik dari kompetensi intelektual, penggunaan metode dan media ajar, hingga ke hal-hal teknis yang dapat mendukung belajar mahasiswa. Semua komponen itu harus dapat meningkatkan proses belajar mahasiswa, entah di dalam kelas maupun di luar jam kuliah.

Ada persoalan yang yang harus diperhatikan dalam konteks belajar mahasiswa Sekolah Tinggi Teologi (STT) Torsina, yaitu kualitas belajar, termasuk di dalamnya adalah tentang kemandirian belajar. Kemandirian belajar bukan hanya sekadar mengerjakan tugas dari dosen di perpustakaan, terlebih ketika dosen berhalangan masuk. Kemandirian belajar 
berbicara tentang kesadaran mahasiswa mengenai kegiatan belajar yang dilakukannya. Kemandirian belajar berarti mahasiswa tidak bergantung pada keberadaan dosen dalam konteks proses belajar dan mengajar. Kemandirian belajar berbicara tentang kemampuan dan kemauan mahasiswa untuk menggunakan waktunya dalam belajar. Kemauan mengandung motif dan minat dari mahasiswa, sehingga mereka melakukan belajar tanpa harus terus disuruh, dipantau atau didorong.

STT Torsina sebagai lembaga pendidikan yang berorientasi pada pengetahuan teologi berdasarkan Alkitab, tidak hanya menstimulasi kemampuan intelektual mahasiswa. Sebagai lembaga yang out put-nya akan mengaplikasikan ilmunya dalam pelayanan gerejawi, maka dituntut juga kehidupan kerohanian yang baik dan tinggi. Disiplin rohani juga diterapkan dalam proses pendidikan di STT Torsina, seperti ibadah (chapel) setiap hari, doa bersama, doa-puasa mahasiswa, dan pelayanan gerejawi. Artinya, selain mahasiswa memiliki pengetahuan teologi secara keilmuan atau teori (kognitif), mahasiswa STT Torsina juga didorong untuk memiliki karakteristik yang sesuai dengan nilai-nilai iman Kristen (afektif) hingga praktek hidup di asrama dan pelayanan (psikomotorik). Ketiga hal tersebut harus ada dalam setiap mahasiswa.

Persoalan keilmuan di STT Torsina tidak jauh berbeda dari kebanyakan STT lain di Indonesia, tergantung pada bingkai teologi gereja yang menaunginya. Namun kembali kepada persoalan di atas bahwa kualitas mahasiswa, dalam konteks keilmuan teologi, harus dipertimbangkan pada beberapa faktor selain mahasiswa sendiri. Pada faktor mahasiswa, perlu adanya semacam stimulasi untuk membawa mahasiswa pada pemahaman tentang nilai belajar. Ada banyak hal yang sudah dilakukan demi meningkatkan kualitas kemandirian mahasiswa dalam belajar, seperti memotivasi lewat firman Tuhan atau menerapkan jam wajib belajar.

Selain itu, ada faktor dosen yang akan menentukan kualitas hasil belajar. Dosen seharusnya dapat menstimulasi (motivasi) munculnya minat mahasiswa untuk belajar secara mandiri. Stimulasi ini bukan sebagai cara untuk melepaskan tanggung jawab mengajar, atau dipakai alasan untuk tidak masuk. Faktor yang kerap sekali membuat mahasiswa kurang terlatih mandiri adalah kurangnya otonomi yang diberikan dosen 
kepada mahasiswa untuk belajar dan mengabaikan gaya belajar mahasiswa. ${ }^{4}$

Kehidupan kerohanian dapat menjadi kekuatan bagi pembentukan kualitas intelektual seseorang. Hal ini sesuai dengan kajian eksposisi terhadap kehidupan Daniel dalam kitab Daniel. Kualitas kehidupan Daniel diakui oleh raja Babel dari masa ke masa, sehingga ia terus dipertahankan untuk menjadi orang penting kedua di istana Babel. Kemampuan Daniel ada dalam posisi semacam perdana menteri merupakan hasil uji kompetensi yang dilakukan pihak kerajaan sehingga mampu mengalahkan para kompetitornya. Keadaan itulah yang mendorong penelitian ini untuk menyumbangkan ide biblikal pada institusi pendidikan, terutama bidang teologi, untuk menstimulasi kehidupan rohani menjadi sebuah potensi untuk meningkatkan kualitas akademis mahasiswanya.

Kualitas kehidupan kerohanian memang bukanlah sebuah hal yang mudah untuk diukur. Kerohanian adalah sebuah potensi atau keadaan yang subyektif, hanya yang bersangkutan yang mengetahui seberapa rohani dirinya. Namun, peneliti beranjak pada premis yang dikatakan

\footnotetext{
${ }^{4}$ Dewi Oktofa Rachmawati, "Penerapan Model Self-Directed Learning Untuk Meningkatkan Hasil Belajar Dan Kemandirian," Jurnal Pendidikan dan Pengajaran, Jilid 43, No. 3 (2010): 177-184.
}

Yesus melalui penulisan Matius, bahwa dari buahnya seseorang dapat dikenali (Mat. 7:16, 20). Kematangan atau kedewasaan seorang yang mengatakan diri rohani adalah buah kehidupan. Kehidupan rohani bukan hanya persoalan berhubungan antara Tuhan dengan umat, namun juga dengan sesama. Artinya, kehidupan rohani tentang hubungan pribadi dengan Tuhan diindikasikan oleh perilaku terhadap sesama atau lingkungan sosialnya.

Stimulasi kehidupan rohani yang dilakukan di STT Torsina selama ini hanya untuk memperlihatkan nilai iman Kristen yang aplikatif. Namun dengan penelitian eksposisi terhadap Daniel, diharapkan ada sebuah goal yang akan dicapai oleh institusi, atau para dosen secara pribadi, bahwa kehidupan rohani yang berkualitas dari mahasiswa akan berdampak pada kualitas akademisnya.

\section{METODE}

Metode yang digunakan dalam penelitian ini adalah eksposisi pada kitab Daniel 1-6. Metode eksposisi digunakan untuk mendapatkan pemahaman mendalam dari sebuah kasus yang disampaikan dengan narasi pada enam pasal kitab Daniel. Penelitian memfokuskan pada persoalan kualitas Daniel yang di atas rata- 
rata (Dan. 6:4), melebih orang yang ada di kerajaan Babel saat itu. Pola eksposisi akan mencari penyebab superioritas Daniel dalam narasi biblikal tanpa harus berasumsi dengan memunculkan ide dari luar teks Daniel 1-6.

Penelitian menggunakan pendekatan eksegesis, yaitu menganalisis kata atau frasa "roh yang luar biasa" yang terdapat pada Daniel 6:4, serta analisis historis untuk mendapatkan latar belakang yang membentuk situasi itu. Setelah memperoleh data biblikalnya, maka pola itu dapat dijadikan prinsip atau kunci yang diterapkan dalam pola kehidupan mahasiswa, khususnya dalam konteks menjadi pribadi yang berkualitas.

\section{Survei Kitab Daniel}

Kitab Daniel termasuk dalam kelompok kitab nabi-nabi besar dalam Perjanjian Lama. Sekalipun ada beberapa kontroversi tentang penulis dan penanggalan, namun indikasi pada Daniel jauh lebih kuat sebagai penulis kitab ini. ${ }^{5}$ Daniel termasuk dalam salah seorang yang ditawan ke Babel ketika Yerusalem dikalahkan dan dihancurkan oleh pasukan Nebukadnezar. Kerajaan Babel menjadi tersohor setelah

${ }^{5}$ Andrew E. Hillton dan John H. Walton, Survei Perjanjian Lama (Malang: Gandum Mas, 1996), 578 berhasil meruntuhkan dinasti Asyur. Keadaan ini cocok sekali dengan gambaran yang ada dalam kitab Daniel, sehingga penetapan tanggal penulisan kitab ini adalah sekitar abad ke-6 SM. ${ }^{6}$

Kitab ini terdiri dari 12 pasal, yang secara garis besar menceritakan tentang Daniel dan ketiga sahabatnya di negeri penjajah Babel. Dalam 12 pasal tersebut Daniel menjadi tokoh utama narasi teologis penulis, sekalipun ada tiga tokoh lain seperti: Sadrakh, Mesakh dan Abednego. Namun kisah mereka berhenti di pasal 3, sementara keseluruhan kitab berikaitan dengan Daniel. Hal yang paling menonjol dalam kitab ini adalah tentang Daniel dengan kemampuan atau hikmatnya serta mimpinya yang lebih bermuatan tema eskatologis.

\section{Konteks}

Teks yang menjadi pembahasan penelitian eksposisi ini adalah Daniel 6:1-4. Pada Daniel 6:4, teks dalam Lembaga Alkitab Indonesia tertulis: "Maka Daniel ini melebihi para pejabat tinggi dan para wakil raja itu, karena ia mempunyai roh yang luar biasa; dan raja bermaksud untuk menempatkannya atas seluruh kerajaannya." Studi biblikal yang bersifat

\section{${ }^{6}$ Ibid.}


analisis teks ini meneliti secara eksposisi makna frasa "memiliki roh yang luar biasa" terkait dengan kualitas Daniel dalam kompetisi pemilihan pemimpin yang membantu raja. Pengertian tentang frasa itu tentunya mempertimbangkan konteks, dalam hal ini keterkaitan narasi Daniel, yakni Daniel pasal 1 hingga 6.

Sastra kitab ini, secara khusus dalam pasal $1-6$, merupakan prosa narasi yang menampilkan tokoh utama Daniel. Penulis kitab memperlihatkan keberadaan Daniel yang tetap menjadi perhatian sekalipun itu negeri penjajah yang menghancurkan negerinya. Situasi politik di bawah penawanan Babel menjadi setting yang mewarnai teologi dari penulisan kitab Daniel. Dalam konteks agama terjadi hal yang kurang menyenangkan, di mana kemunduran dalam ibadah Yahudi menjadi efek tidak langsung dari hancurnya Bait Allah pada saat penghancuran Yerusalem oleh Nebukadnezar. Selain itu ada tekanan yang tidak jarang pada penyiksaan dan pembunuhan terhadap orang-orang yang tidak mau mengikuti sistim agama di Babel. Sadrakh, Mesakh, Abednego, bahkan Daniel pernah menjadi korban atas kebijakan ini.

Semua keadaan ini menjadi pertimbangan dalam memahami tulisan
Daniel. Termasuk bahasa yang digunakan dalam kitab ini bukan hanya Ibrani, melainkan juga bahasa Aram, bahasa yang biasa digunakan oleh penjajah. Dalam beberapa bagian, setelah pasal 6 , bentuk sastera berkembang pada bentuk sastra apokaliptik Yahudi. Dalam konteks kekristenan bagian ini biasa dikaitkan dengan eskatologi Kristen. Itu sebabnya dalam pengelompokkannya kitab Daniel berada dalam kelompok nabi-nabi besar, karena separuh bagian kitab ini berisi tentang nubuatan yang bersifat eskatologis. Namun pembahasan eksposisi ini hanya dibatasi pada pasal 6 saja, tidak mengaitkannya dengan persoalan eskatologis Daniel.

\section{ANALISIS DAN HASIL BAHASAN}

Analisis teks adalah pada Daniel 6:1-4, yang pada bagian sebelumnya sudah ditunjukkan. Perhatian atau titik persoalan adalah pada ayat 4 yang berbunyi: "Maka Daniel ini melebihi para pejabat tinggi dan para wakil raja itu, karena ia mempunyai roh yang luar biasa; dan raja bermaksud untuk menempatkannya atas seluruh kerajaannya." Teks ini menunjukkan tentang keberadaan Daniel yang memenangi pemilihan kepala istana di bawah raja. Ada dua frasa yang menjadi 
titik analisis, yaitu: "melebihi para pejabat" dan "mempunyai roh yang luar biasa".

Dua frasa di atas menunjukkan kualitas Daniel dibandingkan kompetitor lainnya. Pemilihan tersebut dapat dipastikan terjadi dalam kontes kemampuan yang fair karena tidak memungkinkan peluang terjadinya deal politik antara Daniel dan pihak penjajah. Daniel cenderung disepelekan karena dia seorang tawanan dan bukan asli Babel. Sangat kecil sekali adanya dukungan partai politik setempat yang mengalir ke Daniel; jadi jika ia terpilih itu adalah sebuah pertarungan sejati tentang kompetensi Daniel. Penulis menggunakan istilah "melebihi para pejabat" untuk menunjukkan adanya semaca lelang jabatan di sana; dan Daniel menang. Bahasa Aram yang digunakan untuk menunjukkan kata melebihi adalah: (mithnasakh) dari akar kata נִֵֵּ (netsakh) yang berarti: to excel; distinguish oneself. ${ }^{7}$ Artinya, bukan sekadar berbeda namun juga melebihi atau melampaui dari pesaing lainnya, karena Daniel memiliki sifat unggul atau ekselen.

Kompetisi yang diadakan oleh raja saat itu dalam rangka mencari wakil raja untuk menduduki wilayah-wilayah yang berada di bawah pemerintahan kerajaan Babel.

\footnotetext{
${ }^{7}$ Bible Works 7, CD-ROM
}

Jumlah 120 wakil raja yang disebut pada Daniel 6:2-3 tidak mengindikasikan 120 daerah atau wilayah kerajaan Babel yang akan dipimpin oleh wakil-wakil raja, karena bisa saja dua atau tiga orang wakil itu bekerja dalam satu daerah. ${ }^{8}$ Daniel kedudukannya di atas 120 wakil yang dipilih, karena kualitasnya memang di atas mereka semua. Kemampuan Daniel inilah yang tidak dapat ditandingi oleh 120 wakil raja, bahkan ditambah 2 orang yang akan mengepalainya. Kemampuan untuk mengatur 120 wakil raja tidak didapatkan Daniel atas lobi atau pendekatan politis lainnya, kecuali semata-mata Daniel memiliki kemampuan secara administratif dan intelektualnya yang sudah dipertimbangkan raja.

Konteks hubungan bangsa penjajah dan tawanan tidak jauh berbeda dengan konsep tuan atau majikan dengan budaknya. Demikianlah posisi Daniel di dalam lingkungan kerajaan Babel. Dapat dipastikan tidak ada kesempatan intrik dan lobi politik terjadi demi sebuah jabatan, selain murni sebuah ajang uji kompetensi yang dilakukan raja dan pihak kerajaan. Ini lelang jabatan ala Babel, dan Daniel memenangkannya. Kualitas intelektual

\footnotetext{
${ }^{8}$ Lynne Newell, Tafsiran Kitab Daniel (Malang: SAAT, 2000), 168-170
} 
dapat dipastikan juga menjadi modal atau dasar pemilihan raha atas dirinya. Pengetahuan Daniel di atas rata-rata.

Frasa kedua yang ada dalam konteks bahasan teks adalah: "mempunyai roh yang luar biasa". Frasa ini muncul sebagai faktor penyebab dari kemampuan Daniel tersebut. Istilah "roh yang luar biasa" diambil dari

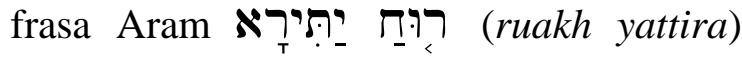
yang dalam beberapa terjemahan diartikan excellent (KJV) atau extraordinary (NAS). Newell mengatakan bahwa istilah "roh yang luar biasa" mencakup kemampuan, hikmat dan sifat yang dihasilkan dari kehidupan rohani yang sangat baik. ${ }^{9}$ Artinya, ada pengertian bahwa itu adalah tingkat kedewasaan rohani seorang Daniel yang dapat dikatakan juga di atas rata-rata.

\section{Hikmat dan Roh Allah}

Mungkin akan muncul pertanyaan, mengapa kerohanian Daniel yang menjadi penyebab kepintaran atau kemampuan intelektualnya. Sepertinya ini tidak dapat dibantah dalam konteks kehidupan orang Yahudi atau Israel, bahwa kemampuan seseorang yang di atas rata-rata merupakan campur tangan Allah dalam diri orang tersebut. Perhatikan paradigma yang dinyatakan oleh seorang yang dianggap

\footnotetext{
${ }^{9}$ Ibid., 171
}

paling berhikmat di masanya, Salomo, dalam Amsal 1:7, “Takut akan TUHAN adalah permulaan pengetahuan, tetapi orang bodoh menghina hikmat dan didikan." Hal ini tidak dapat dipandang rendah begitu saja, karena dalam beberapa konteks orang yang dipenuhi Roh Allah dalam Perjanjian Lama memperlihatkan indikasi itu.

Perhatikan dua orang Bezaleel dan Aholiab yang menjadi ahli dalam mendirikan tempat ibadah (Kel. 36;1-2) ketika Roh Tuhan ada pada mereka. Yusuf yang dapat mengalahkan semua ahli nujum dan tafsir mimpi Mesir, dikatakan oleh Firaun saat itu, bahwa kemampuannya adalah hasil dari dipenuhi oleh Roh Allah (Kej. 41:38). Ada banyak manifestasi terjadi ketika Roh Allah memenuhi seseorang dalam konteks Perjanjian Lama, selain kekuatan seperti para Hakim juga dalam bentuk hikmat atau pengetahuan dan keahlian. Kemampuan mereka yang dipenuhi oleh Allah akan melampaui orang-orang pandai sekalipun.

Hikmat menjadi unsur penting dalam kepandaian seseorang pada masa Perjanjian Lama. Namun dalam konteks kekinian hikmat juga mamiliki fungsi yang sama, penyebab kemampuan seseorang. Salomo menekankan hikmat sebagai kemampuan 
atau dinamika berpikir yang menghasilkan kreasi, sehingga orang memiliki kreativitas dalam hidupnya. ${ }^{10}$ Hikmat itulah sebagai potensi kemampuan extraordinary atau excellent seseorang, termasuk dalam hal intelektualitasnya. Pengkhotbah pun menyebutkan bahwa hikmat adalah unsur utama dalam keberhasilan (Pengkh. 10:10). Siahaan menambahkan, bahwa hikmat dan keahlian adalah dua hal yang tumpang tindih digunakan dalam Keluaran 31:3. ${ }^{11}$

Istilah roh yang luar biasa dapat juga dimengerti dalam konteks budaya. Umumnya, istilah roh dapat merujuk pada hal yang menjiwai seseorang. Pada dasarnya istilah roh dan jiwa adalah dua hal yang terkadang tumpang tindih dalam penggunaannya. Roh dan jiwa dipandang sebagai dimensi hidup yang imateri, yang tidak terlihat, dibedakan dengan jasmani atau materi. Istilah spirit dalam bahasa Inggris tidak senantiasa diartikan roh, bisa juga berarti semangat. Ini dapat dipahami bahwa istilah roh bukan sekadar menunjuk kehidupan kerohanian, melainkan bisa

\footnotetext{
${ }^{10}$ Harls Evan Rianto Siahaan, "HIKMAT SEBAGAI IMPLIKASI PENDIDIKAN KRISTIANI: REFLEKSI 1 RAJA-RAJA 3:1-15," DUNAMIS (Jurnal Teologi dan Pendidikan Kristiani) 1, no. 1 (2016): 15-30, http://www.sttintheos.ac.id/ejournal/index.php/dunamis/article/view/99.

${ }^{11}$ Ibid.
}

berarti semangat atau sesuatu yang mengikat, menguasai diri seseorang; bisa juga berupa kehidupan di dalam atau habit. Contoh sederhana, ketika seseorang terbiasa dengan hidup mencuri atau berjudi, dan seakan itu sulit terlepas dari dirinya, maka orang itu disebut terikat oleh roh mencuri atau roh judi. Jadi, roh dapat menunjuk sebuah kebiasaan atau budaya seseorang.

\section{Kualitas Kerohanian Daniel}

Kemampuan atau kualitas intelektual Daniel disebabkan oleh kualitas hidup rohaninya yang di atas rata-rata. Penggunaan istilah extraordinary (NAS) atau excellent (KJV) mengindikasikan bahwa kehidupan rohani Daniel bukanlah di bawah standar. Istilah itu tidak muncul begitu saja, namun menjadi semacam konklusi dari beberapa hal yang ditunjukkan penulis dari pasal 1 hingga 6 . Ada semacam kebiasaan hidup rohani, katakanlah semacam disiplin rohani yang dilakukan oleh Daniel sebagai orang yang takut akan Allah.

\section{Tidak Menajiskan Diri (Dan. 1:8)}

Kualitas rohani yang pertama adalah tidak menajiskan diri. Ungkapan ini muncul di dalam Daniel 1:8, "Daniel berketetapan untuk tidak menajiskan 
dirinya..." Dalam ayat ini disebutkan perihal makanan. Mengapa makanan dikaitkan dengan disiplin rohani Daniel? Apakah ini tidak terkesan memaksakan?

Dalam konteks ibadah Yahudi, ada halhal yang telah diatur oleh Hukum Taurat sebagai makanan yang haram atau dilarang (Im. 11:1-47). Makanan yang dianggap haram tidak boleh dikonsumsi karena dianggap melanggar hukum Tuhan dan berdosa. Daniel tahu betul makanan yang seperti apa yang disajikan kepadanya, sehingga ia bisa memutuskan haram atau tidak bagi dirinya. Ketetapan Daniel untuk tidak memakan hidangan raja merupakan bentuk ekspresi imannya yang menjaga hatinya tetap murni. Terjemahan LAI tidak menerjemahkan kata לב? (lev) dalam frasa

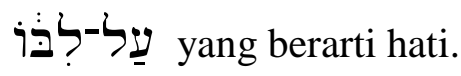

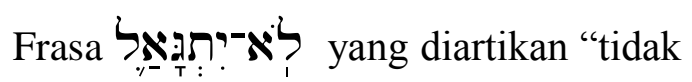
menajiskan" (bisa juga tidak mencemarkan atau menjaga tetap murni) terkait dengan ליב kata pada awal kalimat. Artinya penolakan Daniel atas makanan tertentu merupakan cara untuk tetap menjaga hatinya tetap murni, tidak tercemar. Ini merupakan disiplin rohani Daniel untuk membangun roh yang luar biasa. Kata kuncinya adalah menjaga kemurnian hati sesuai dengan ketentuan firman Tuhan.

\section{Persekutuan Bersama Orang Percaya (Dan. 2:17-19)}

Kebiasaan berikut yang dilakukan Daniel adalah, ketika masalah terjadi ia selalu membawanya dalam doa bersama dengan orang benar. Pada saat itu orang benar yang bersama Daniel adalah Sadrakh, Mesakh dan Abednego. Konteks ayat ini adalah muncul ancaman kematian bagi orang bijak yang ada di Babel jika mereka tidak mampu menceritakan mimpi raja sekaligus mengartikannya. Jika hanya mengartikan mimpi mungkin tidak terlalu masalah buat para Kasdim dan orang bijak. Namun persoalan terjadi ketika raja tidak mau menceritakan mimpinya, namun meminta para orang bijak itu menceritakan dan sekaligus mengartikannya.

Ketika masalah itu diceritakan Ariokh, Daniel lantas meminta waktu kepada raja untuk meminta hikmat pada Allah demi memenuhi keinginan raja. Dalam menghadapi persoalan seperti itu, Daniel mengajak ketiga sahabatnya untuk berdoa dan bergumul bersama agar memperoleh jawaban Allah. Kebersamaan dengan orang percaya atau orang benar merupakan pola dan kebiasaan yang dilakukan Daniel 
sebagai nilai kehidupan rohaninya. Kebersamaan ini tidak hanya menunjukkan solidaritas pendatang di negeri buangan, namun lebih kepada pola yang diajarkan oleh nenek moyang mereka sebagai umat Allah.

\section{Disiplin Rohani (Dan. 6:11)}

Teks ini memberitahukan bahwa Daniel memiliki kebiasaan dalam kehidupan rohaninya, di mana tiga kali dalam sehari ia berdoa kepada Allah. Ini sebuah bentuk disiplin rohani Daniel. Ia membangun kehidupan doa menjadi sebuah kebiasaan sehari-hari. Sekalipun poin ini muncul di ayat 6 , namun frasa “... seperti yang biasa dilakukannya" menunjukkan adanya pola yang sudah dilakukan sejak lama dan telah menjadi habit Daniel.

Kebiasaan yang dilakukan tiga kali dalam sehari menunjukkan ketekunan dan kedisiplinan Daniel dalam berdoa. Sekalipun hidup dalam sebuah suasana yang tidak mendukung, di tanah asing dan tidak mendukung kegiatan beribadah, Daniel tetap taat melakukan doa. Disiplin rohani yang dilakukan Daniel inilah yang membentuk kerohanian yang di atas ratarata; roh yang luar biasa.

\section{Stimulasi Kerohanian Mahasiswa}

Kegiatan sehari-hari mahasiswa STT Torsina tidak lepas dari kegiatan yang berbau ibadah, seperti berdoa dan membaca firman Tuhan. Dari pagi sebelum perkuliahan dimulai, semua mahasiswa mengikuti doa pagi. Siang hari ada ibadah chapel bersama, begitu pun malam hari. Selain itu mahasiswa memiliki jadwal dan kelompok doa yang dibuat secara mandiri. Kegiatan kerohanian berlanjut pada kegiatan pelayanan weekend setiap hari Jumat hingga Minggu di gereja yang ditunjuk. Artinya, kegiatan kerohanian mahasiswa STT Torsina tidak sudah lebih dari cukup.

Persoalan kualitas kemandirian belajar mahasiswa masih perlu ditingkatkan lagi. Prestasi belajar dan kualitas pengetahuan ditingkatkan dengan menstimulasi motif dan minat belajar mereka. Dalam sebuah penelitian menunjukkan semakin tinggi tingkat kemandirian belajar mahasiswa cenderung makin tinggi hasil belajarnya. ${ }^{12}$ Seperti diungkapkan di atas, bahwa kemandirian menuntut adanya sikap bertanggung-jawab, ketidakbergantungan,

\footnotetext{
${ }^{12}$ Irzan. Tahar and Enceng, "Hubungan Kemandirian Belajar Dan Hasil Belajar Pada Pendidikan Jarak Jauh," Jurnal Pendidikan Terbuka dan Jarak Jauh, Vol. 7, No. 2 (2006): 99-100.
} 
disiplin, inisiatif dan kontrol diri dari para mahasiswa dalam melakukan proses belajar. Sikap-sikap tersebut direfleksikan dalam pola hidup Daniel yang digambarkan dengan frasa "roh yang luar biasa."

Kehidupan Daniel memiliki sikap yang bertanggung jawab atas pekerjaannya, disiplin, inisiatif, kontrol diri, serta tidak bergantung pada orang lain. Daniel tidak melakukan pekerjaannya ketika ada yang melihat atau mengawasi, karena ia tahu apa yang sedang dilakukannya dan untuk siapa itu dilakukan. Belajar dari apa yang dilakukan Daniel seharusnya hal itu juga dapat terjadi pada setiap orang yang percaya pada firman Allah, termasuk mahasiswa STT Torsina. Narasi kitab Daniel tidak hanya menyajikan cerita masa lalu, namun memberikan prinsip yang hidup dan jaminan, karena itu adalah firman Allah yang berkuasa dan tidak dibatasi oleh masa.

Kebiasaan atau disiplin rohani yang dilakukan oleh Daniel bukan hanya sebatas pada kegiatan ibadah atau ritual keagamaan seperti doa dan membaca firman. Sikap Daniel menolak memakan makanan raja adalah gambaran tentang nilai terhadap halhal yang umum dilakukan. Makan adalah hal yang biasa saja, bukan kegiatan ritual ibadah, kecuali hal itu berkaitan dengan korban persembahan. Namun ide yang disampaikan lewat narasi ini adalah Daniel menjaga kehidupan rohani (hatinya) dengan melakukan hal-hal umum demi menjaga kemurnian hatinya. Artinya, kegiatan umum yang dilakukan Daniel itu dilakukannya dengan nilai atau motif rohani. Hal ini senada dengan yang dikatakan Paulus dalam Kolose 3:23, "Apapun juga yang kamu perbuat, perbuatlah dengan segenap hatimu seperti untuk Tuhan dan bukan untuk manusia."

Kuncinya pada bagian ini, mahasiswa harus menjadikan kegiatan belajar itu sebagai sebuah ibadah, sebagai cara untuk menjaga hati tetap murni. Jika mahasiswa menyadari bahwa kegiatan belajar adalah sebuah cara untuk memurnikan hati, maka itu dapat menjadi modal dasar untuk memperoleh roh yang luar biasa. Kemandirian belajar dimulai dari pemahaman mahasiswa tentang hakikat dan tujuan belajar, diikuti kesadaran untuk melakukannya untuk memperoleh roh yang luar biasa.

Disiplin rohani yang dilakukan Daniel dengan setia dan tekun berdoa tiga kali sehari menghasilkan kebiasaan atau semangat (roh) yang luar biasa. Disiplin rohani berimplikasi pada habit atau penciptaan budaya disiplin termasuk dalam 
belajar, karena yang dipelajari adalah tentang firman Tuhan. Penciptaan habitat rohani berdampak pada kebiasaan baik dan positif yang berkaitan dengan tanggung jawab. Itu yang dilakukan Daniel, ia melakukan tanggung jawabnya. Mahasiswa yang rohani mengerti tanggung jawabnya, yaitu belajar. Artinya, kedewasaan rohani akan diperlihatkan dengan melakukan tanggung jawabnya.

Stimulasi kehidupan rohani mahasiswa STT Torsina pada akhirnya akan terus dilakukan dengan mempertimbangkan temuan eksposisi karakteristik Daniel atas status luar biasa (ekselen). Menurut William Dyrness, konsep roh dalam Perjanjian Lama, jika dikaitkan dengan manusia maka itu menunjuk pada sebuah ungkapan psikologis yang berarti dorongan hati atau watak seseorang. ${ }^{13}$ Ungkapan psikologis berkaitan erat juga dengan kegiatan berpikir. Secara tidak langsung dapat diartikan juga bahwa istilah roh yang luar biasa menunjuk pada kemampuan intelektual dan watak yang luar biasa. Stimulasi rohani seperti inilah yang akan direkonstruksi dalam kehidupan mahasiswa STT Torsina.

\footnotetext{
${ }^{13}$ William Dyrness, Tema-tema dalam Teologi Perjanjian Lama (Malang: Gandum Mas, 2004), 184
}

Mahasiswa tidak sekadar melakukan kegiatan rohani dari hari ke hari sebagai sebuah kegiatan rutin belaka. Kegiatan ibadah mereka menjadi pembentukan kerohanian tentang kualitas diri yang sejati. Ibadah seperti doa dan membaca Alkitab tidak berhenti pada perenungan tentang Tuhan dan dirinya saja dalam suasana ritual, melainkan berdampak pada kegiatan umum yang setiap hari dilakukan, termasuk belajar. Kegiatan ibadah tidak menghabiskan energi sehingga tidak tersisa lagi untuk belajar, namun sebaliknya menghasilkan motif dan minat yang kuat dan tinggi untuk belajar, karena itu bagian dari memurnikan hati.

\section{KESIMPULAN}

Analisis teks eksposisi Daniel 6:1-4 menghasilkan beberapa poin simpulan tentang frasa roh yang luar biasa yang dimiliki Daniel dalam kaitannya dengan kegiatan kemandirian belajar mahasiswa STT Torsina adalah sebagai berikut:

Pertama, narasi eksposisi kitab Daniel tentang keunggulan Daniel dibandingkan para kompetitornya merupakan pesan teologis yang dapat diaplikasikan dalam kehidupan orang percaya, karena itu adalah firman Tuhan yang berkuasa dan berotoritas. Temuan dan pesan eksposisi 
atas nas tersebut bukan sekadar pesan moral namun juga norma teologis yang berlaku bagi siapa yang mempercayai firman Allah.

Kedua, roh yang luar biasa adalah faktor penyebab keunggulan Daniel, sehingga keunggulan mahasiswa STT Torsina pun akan diperoleh lewat membangun disiplin hidup rohani yang luar biasa. Membangun roh yang luar biasa dilakukan dengan menerapkan disiplin rohani dan kebiasaan rohani yang tinggi di atas rata-rata. Disiplin rohani yang tinggi menghasilkan kedewasaan rohani yang berimplikasi pada rasa bertanggung jawab atas apa yang menjadi tugasnya. Mahasiswa dengan kerohanian yang dewasa akan melakukan tugasnya dengan penuh tanggung jawab.

Ketiga, membangun roh yang luar biasa bukan hanya dilakukan lewat kegiatan rohani seperti ibadah atau pelayanan, doa dan membaca firman, melainkan juga dengan melakukan kegiatan yang umum dengan hati yang luar biasa. Artinya, mahasiswa STT Torsina melakukan kegiatan belajar dengan menjadikannya sebagai cara untuk menjaga kemurnian hati atau imannya.

\section{DAFTAR PUSTAKA}

Dyrness, William. Tema-tema dalam

Teologi Perjanjian Lama, Malang:

Gandum Mas, 2004.

Hillton, Andrew E. dan Walton, John H.

Survei Perjanjian Lama, Malang:

Gandum Mas, 1996.

Lobby, J.T. Lochmono. Belajar

Bagaimana Belajar, Jakarta: BPK

Gunung Mulia, 1994.

Newell, Lynne. Tafsiran Kitab Daniel, Malang: SAAT, 2000

Rachmawati, Dewi Oktofa. "Penerapan Model Self-Directed Learning Untuk Meningkatkan Hasil Belajar Dan Kemandirian." Jurnal Pendidikan dan Pengajaran 43, no. 3 (2010): 177-184.

Siahaan, Harls Evan Rianto. "HIKMAT SEBAGAI IMPLIKASI PENDIDIKAN KRISTIANI: REFLEKSI 1 RAJA-RAJA 3:1-15." DUNAMIS (Jurnal Teologi dan Pendidikan Kristiani) 1, no. 1 (2016): 15-30. Accessed May 11, 2017. http://www.sttintheos.ac.id/ejournal/index.php/dunamis/article/view 199.

_. "Hikmat Sebagai Implikasi Pendidikan Kristiani: Refleksi 1 RajaRaja 3:1-15." DUNAMIS (Jurnal Teologi dan Pendidikan Kristiani) 1, no. 1 (2016): 15-30. www.sttintheos.ac.id/ejournal/index.php/dunamis.

Tahar, Irzan., and Enceng. "Hubungan Kemandirian Belajar Dan Hasil Belajar Pada Pendidikan Jarak Jauh." Jurnal Pendidikan Terbuka dan Jarak Jauh 7, no. 2 (2006). 